\title{
Scientific Research in Stanisław Leszczyński Academy in Nancy in the Field of Agriculture and Its Practical Applications (1750-766)
}

\author{
Małgorzata Durbas \\ Institute of History, \\ Academy of Jan Dlugosz in Częstochowa \\ al. Armii Krajowej 36a, \\ Częstochowa 42-200, Poland \\ E-mail: skwarczynskam@wp.pl
}

\begin{abstract}
Scientific societies and academies, which represented the path to knowledge and the way of constructing theoretical sciences, constituted a distinctive feature of the intellectual life in mid-eighteenth-century Europe. These societies worked towards knowledge-in its broad sense-within the country and towards the cooperation of scholars to exchange scientific achievements and introduce technical innovations into practice. The Royal Society in Nancy (Société Royale des Sciences et Belles Lettres), now called the Stanisław Academy, established in 1750, started research in various topics in the field of agriculture. They focused on methods of improving soil efficiency and the use of modernised farming machines in Lorraine and Bar. King Stanisław Leszczyński, founder of the institution, took great care in academic research activities, encouraging researchers to hold public speeches, advising and searching for novelties in a field, such as, for example, a new species of grass from England. He considered agriculture the driving force in the development of societies and believed that an increase in farming production would benefit common wealth. He used many innovations in his properties to underline the importance of work in agriculture and popularise various kinds of novelties.
\end{abstract}

Keywords: academies, agriculture, Lorraine, scientific research, scientific societies, Stanisław Leszczyński 
The last Duke of Lorraine and Bar (Durbas, 2016, pp. 449-463), King Stanisław Leszczyński, as a true representative of the Enlightenment, managed to match his charity actions in Lorraine (Précis des fondations..., 1758, pp. 188-194) with the scientific movement of Western Europe. He established the Royal Society in Nancy (Statuts de la Société Royale des Sciences, 1751) with a founding edict in 1750, which later changed its name into Academy Stanisław (Durbas, 2013). The Academy was founded rather late in comparison with other institutions in France in the $18^{\text {th }}$ century-later, for example, than the ones in Dijon (1725), Marseilles (1726), Arras (1737), Rouen (1744), and Toulouse (1730) (Michaux, 2008, p. 82). The mission of the Academy was to support the sciences, develop intellectual life in different fields and encourage internal competition. One of the main aims of such institutions, especially the Scientific Society in Nancy, was utilitarianism in research and technical solutions.

The aim of this article is to discuss the scientific studies presented for the Academy of Science in Nancy and practical projects implemented in the field of modern agricultural cultivation of crops in the years 1750-1766.

It is necessary to mention that the importance of land and introducing new ways of land cultivation were the priorities of academic research in Paris, where Académie royale des Sciences started to publish its agricultural research materials in the 1750s (Duhamel du Monceau, 1750-1757). All changes in theoretical and practical sciences shared one feature which distinguished them from teaching. Scientific research was a private matter of individuals and, like art, science was regarded a vocation rather than a job. According to Stefan Amsterdamski (1983, p. 97), scientific research was treated as a hobby and amateur scholars came not only from the upper class but also from the middle class of townspeople. The large number of encyclopaedists proved the immensity of non-institutionalised intellectual life in France in the mid-eighteenth century. Diderot and d'Alembert's Encyclopedie was the work not only of professionals but also of dilettantes and amateurs (Rostworowski, 1998, p. 415).

In Stanisław Leszczyński Academy, research was connected to new ways of preparing the soil and using improved farming machines in Lorraine. Some of the presented devices, which were modern for the time, could be found in Poland even as late as in the $20^{\text {th }}$ century. Leszczyński believed that land was the basic good and agriculture was the driving force in the development of the society-his ideas were similar to physiocratic ideas that were introduced several years later. 
The topics taken up by the Société Royale des Sciences et Belles Lettres in Nancy illustrated contemporary ideas in natural sciences and literature. The topics were discussed by teams of several people, possibly consisting of scholars appointed by the king, the founder. Famous physiocrats were invited to the Royal Society in Nancy as well. Henry Pattullo (Voisine, 1974), the famous foreign physiocrat, agronomist and the author of Essai sur l'amélioration des terres (Pattullo, 1758), became an associated member of the Society. In 1760, Louis-François de Menon, Marquis de Turbilly, also became an associated member. He published a piece, entitled Mémoire sur les défrichements, about the preparation of soil for adaptation in wastelands (Turbilly, 1762).

This work attracted considerable interest in scientific circles and the French court and caught the attention of the aged and almost blind King Stanisław, who invited Marquis de Turbilly to the Society in Nancy. The Marquis was honoured and accepted the invitation. He also promised to come to Lorraine from the side of Germany and survey the land to ascertain the need of clearing and the new way of cultivation (Sauvy \& Hecht, 1965). Marquis de Turbilly gave a speech upon his arrival at the Stanisław Leszczyński Academy in Nancy on the popular physiocratic trend which emphasised the importance of work and agriculture as the only source of wealth. De Turbilly reminded that agriculture is the basis of happiness and the power of countries, the mother of trade and crafts (P.V. ms., 1759-1765, pp. 220-227). The Marquis gave a very interesting historical retrospect of the agrarian culture of ancient countries and pointed at the fall of this culture in the modern age. Using the example of the Assyrian people, the Hanging Gardens and Egyptians with their efficient agriculture, he underlined the advanced ancient knowledge and ideology, which put the agriculture at the top of the hierarchy of values. De Turbilly, who after a career in the army became engaged in agricultural experiments, became famous for the reviews of clearing, firing and fertilising the soil (Bonnefont, 2006, p. 53).

Agriculture was considered the most important discipline by King Stanisław (Nouvelles découvertes.., n.d.) He encouraged scholars to start research in that field, which was conducted in two ways:

- theoretical—novelties were submitted and discussed, and

- practical (experimental) — new and old methods of cultivation were used simultaneously and the results were compared to each other.

The article first presents the theoretical part to explain these scientific processes. 
François-Alexis Credo, a member of Stanisław Leszczyński Academy who was interested in chemistry and botany, started experiments related to new methods of cultivation and gaining more efficient crops on the lands of Lorraine. As he mentioned, it had been an order from King Leszczyński (Credo, 1758, p. 4).

Credo experimented with cultivation and led experiments with the use of modern farming machines (P.V. ms., 1754-1759, p. 593). In 1756, he became the attorney for King Stanisław for introducing innovative farming machines in Chanteheux, one of the king's estates - a seed drill for continuous sowing of the seed and a plough (P.V.ms., 1754-1759, pp. 240-241). Credo discussed the new process of farm production used on the land bought on the King's orders. The lot, sized three morgen, adjoined the property of the Jesuit organisation Mission Royale. It was divided into three arable fields. Credo began his work by giving reasons for the need of precise preparation of soil, which required ploughing at different depths, depending on the type of land. He introduced an effective method of weeding as part of modern cultivation which had not been sufficiently used. For a few years, he sowed different crops-domestic, foreign and a new variety of rye - on the experimental fields. Credo introduced his innovative and versatile methods to prepare soil with the new farming machines used in France. The next part of his work consisted of a report with detailed calculations on the amount of crops, their quality and the possibility of using new farming tools. Credo announced the results in his dissertation Mémoire sur la nouvelle culture (P.V. ms., 1754-1759, p. 596; Credo, 1758) based on his statistics and record lists. He was even considered for an informal award by his principal, but the prize was not awarded for science.

However, the published results of the experiments in Lorraine were acknowledged as a great piece of research at Académie royale des Sciences in Paris. The treatise Mémoire sur la nouvelle culture was qualified for publication in the collaborative work Traité de la Culture des Terres (Duhamel du Monceau, 1758, pp. 20-39). Credo's next treatise presented to the Society in Nancy focused on the new method of preservation of seeds (P.V. ms., 1754-1759, p. 559).

Mémoire sur Ray Grass ou Faux Seigle is another, very interesting work presented to the Royal Society in Nancy; it discusses modern cultivation, and was published anonymously in the fourth volume of Mémoires de la Société Royale à Nancy (M.S.R.N., 1759, pp. 124-129). The study was presented to the Society in 1759 (P.V. ms., 1759, pp. 89-97) and as part of a broader edition to King Stanisław Leszczyński (Miroudot, 1760), who ordered that the work be printed and disseminated in Lorraine. The author, monk Jean-Baptiste Miroudot du Bourg, 
was appointed d'aumonier à brevet by King Stanisław. Father Miroudot du Bourg (1722-1798) was first appointed to the Cistercian monastery in Barrois. He was interested in agriculture, which connected him to King Leszczyński for several years. In 1776, he was delegated from France to Baghdad as a bishop and consul. Mirodout became infamous in Rome as he took an oath on the Civil Constitution of the Clergy (Michaud, 1821, pp. 142-143; Delarc, 1884-1897, p. 413).

The content of the work is so interesting that it deserves a short note in this article. The work describes experiments on gaining more efficient crops which were started by the king and were continued after the work was published. The author informs that the experiments of cultivating darnel were carried out in Lorraine in about 1756 . He writes that agriculture is undergoing great changes and mentions the dominance of English agriculture over that of Lorraine. Englishmen created artificial pastures and achieved very efficient modern fodder, beneficial to the soil.

Mirodout (1760, p. 37) underlines that he created artificial pastures on the territory of Malgrange on the orders of King Stanisław, which enabled him to improve the quality of even the most barren soil. Fabaceae (legumes) and a new type of grass, ray grass, not known in France before, was sown in the part of the fields used for corn. The plant did not have a French name, which is why some botanists considered it couch grass, and sometimes the name was translated as rye (M.S.R.N., 1759, p. 125). The plant belongs to the group of perennials which grow on all types of soil, even the "hungry" ones. It does not need fertilising and is inexpensive to cultivate. The only thing that had to be done before sowing was to plough the land. Spring was the best sowing time. Between 48 and 50 pounds of ray grass with 2 pounds of medick or clover or 1.5 bushels of oats were used to sow the area of one of the Lorraine lots (Matkowski \& Ciesielska-Borkowska, 1928, p. 466). The other plants were necessary to strengthen the root system and support the ear. The first year of cultivation gave a very good but single harvest; in the following years there were up to three harvests. Ray grass grown as fodder to be used in cattle, horse and sheep breeding was one of the most efficient plants. Mirodout informs that a number of experiments were conducted to cultivate this plant, the results of which were not as excellent as the English experiments, but still very productive. An additional leaflet revealed important information: the Lorraine nobility, officers of Parliament Regional, people in high positions and even enlightened minds were growing experimental crops similar to Miroudot's in 
Malgrange under the guidance of King Stanisław and the city (Skwarczyńska [Durbas], 2005, pp. 113-120).

At that time, as the authors claim, the planting of 20 or 30 morgen of a new crop was rather common in Lorraine. The owner of Château de Fléville (Lambel, 2003, pp. 119-130), Marquise Anne Desarmoises (Des Armoises), had good relations with King Stanisław. According to the contemporary owner of the chateau in the suburbs of Nancy, Count Thierry de Lambel, King Leszczyński assigned monk Miroudot du Bourg, a specialist of des prairies artificielles (artificial grasslands), in Chateau de Fléville to create beautiful lawns in the French formal garden. Marquise Anne Desarmoises, who lived there in the $18^{\text {th }}$ century, increased the harvest every year. The grass was slowly changed into a lawn grass with the help of Father Miroudot. (Lambel, 2003, pp. 119-130)

The experimental fertilising of the soil was used in order to increase the harvest. Miroudot, applying his own method, mentioned that this is a very important factor in increasing the quality and quantity of the crops. This method consisted in mixing the hungry soil with loam or alluvial soil. He described the two ways as follows: 100 carriages of good soil was mixed with hungry soil or, the opposite, 200 carriages of sand or grit was added to the terrain with loamy soil. This type of mixture, as he informed, was used to enrich land around Malgrange (Miroudot, 1760, p. 45). He followed the example of Henry Pattullo, agronomist, physiocrat and a member of the Society (P.V. ms., 1759-1765, p. 383), and his Essai sur l'amélioration des terres (Pattullo, 1759). Father Miroudot contacted the Chairman of the Parliament in Besançon and the Society of Agriculture, Trade and Art in Brittany, where similar experiments were carried out to popularise cultivation (M.S.R.N., 1759, p. 129).

King Stanisław Leszczyński was the main initiator of agricultural researches in the Stanisław Leszczyński Academy in Nancy. He was also the initiator working with the new method of preparing the soil and using better farmimg machines in Lorraine.

This field was considered by the Polish King, Duke of Lorraine and Bar, as one of the most important branches of knowledge (Nouvelles découvertes pour l'avantage..., p. 6). He said that: "everyone who learns about the superiority of agriculture over the other branches of knowledge, will not hesitate to spend his time and engagement in research in improving the mechanics which is connected to this social need". 
In 1756, the Academy received an anonymous text, Memoire, about the new useful machines and other inventions. Simultaneously, the printed version of the anonymous Nouvelles découvertes pour l'avantage et l'utilité du public ('New discoveries for public benefit and utility') was dedicated to A Messieurs de la Societé Royale des Sciences, Arts et Belles-Lettres de Nancy. The author, King Stanisław Leszczyński, expressed his admiration for the advancement of sciences and arts in Lorraine since the time the Academy was created using the words "I am grateful for the care in perfecting the talents and stimulation for competition and making it possible for the intelligent researchers to submit their projects to the Academy." (Nouvelles decouvertes..., n.d., p. vj). King Stanisław underlined that his work is the result of various experiments he had seen with his own eyes and collected for his own use. In the preface, he announced a genius invention for a modern way of cultivation, the only fault of which was that it was invented too late. While waiting for that time, Stanisław believed that this invention would be used only when its public approval triumphed over the custom treated as law. He presented the easiest way of ploughing, more plentiful production of crops and the method of threshing that did not require any effort. The king added some more interesting inventions to this list. He was sure that clever minds eager for knowledge could improve those inventions. "In order to, let me say, heat up the old ideas and nurse those seeds better than I did this, I ask [the researchers] to continue and not to bereave the society of the results that can come from those seeds" (Nouvelles decouvertes..., n.d., p. vj).

The inventions that were introduced in the press, complied with the conditions of utilitatis (utility) and were presented to the Royal Society in Nancy, are worth a closer look. After the academicians acquainted with the text, the plough, new for that time, was the most controversial one. There is a note in the protocols of the Society's meetings in which the inventor (King Stanisław) was compared to Cincinnatus bound to his plough: "The plough no longer boasts of having seen Cincinnatus attached to its share...” (P.V. ms., 1754-1759, p. 241).

In reality, two types of ploughs were presented to the academicians. One of them was an improved, complicated tillage plough, operated by only two horses. The experiments were carried out on different types of soil and even on the hard surface of a county road that had been used for many years. The experimental fields were in Jolivet (the estate of 162 hectares close to Lunéville) and its appurtenances (Skwarczynska [Durbas], 2005, p. 105). At first sight, the new plough did not differ from the ones commonly used. The main parts were the same but the way of construction made it better in many respects. The ploughshare control, which 
allowed changing the depth and width of the ploughed area, was the innovative element (Nouvelles découvertes..., n.d., p. 4).

The second plough was designed for swampy soils on which the common wheeled plough could not be used. There were also two horses used for operating but the way of harnessing them was different: the horses were attached to a thill rather than a drawbar, thus to a carriage with two drawbars. The lack of wheels enabled tillage on hard, firm soils which were difficult to access. This plough was also used on the Jolivet field to the satisfaction and approval of farmers. The researches and experiments using modern and improved machines were introduced in Paris for the Academy of Sciences under the supervision of M. de Duhamel. King Stanisław recommended making changes, changing different parts, and improving some of the mechanisms which led to the greater efficiency of the farming machines (Durbas, 2013, pp. 171-201).

Producing more plentiful crops (production plus abondante de la semence) was achieved with a detailed recipe for a chemical solution mixed with nutritive substances, that is, manure. This would be nothing uncommon, except for the fact that the king added a new step to its process of use: soaking the grains in diluted solution before sowing in the field increased yields. The grains were soaked for 24 hours, after which they were dried and seeded. The solution was also used for watering flowers, vegetables and other plants. Even a single injection of this substance accelerated plant growth. (Nouvelles découvertes..., n.d., pp. 10-11) The experiments with manure took also place in the area of Jolivet called Ménagerie du Roi dans Recueil de plans... ("The King's menagerie of collection of plants", Héré, 1750) and they benefited the farmers and the royal vegetable garden. Also, the solution was used for fertilising flowers in King Stanisław's beautiful gardens (Skwarczyńska [Durbas], 2005, pp. 107-108).

The next invention was a new model of threshing device, which later became to be called a thresher-machine à battre le bled (Nouvelles découvertes..., n.d., pp. 12-22). Owing to its innovative construction, the machine was able to thresh the corn almost without effort and cost, as was written in the description. Only one man and one horse was used to activate and operate it. The convenience of using the device involved economical factors (saving human labour and greater efficiency). The advantages of using machine à battre le bled were set against the old time-consuming methods of gaining seeds with a flail. The machine's description claimed that one or two of these devices would be sufficient for one village. The description also mentioned that to decrease the costs, the power of water current could be used instead of the horse. There are two illustrations 
presenting the machine from the technical point of view that complete the image and demonstrate the main operation principle of the thresher-multiplied transmission of forces (Nouvelles découvertes ..., n.d., p. 22).

A simple thresher (la batteuse simple), which could be used by simple farmers, was presented as well. "Peasants, preoccupied with the present, very seldom see in an economic way beyond the day which dawns (Nouvelles découvertes..., n.d., p. 21). King Stanisław presented the second model of thresher as considerably cheaper and simpler in construction. This machine had been, and was, as the king underlined, used in Einville-au-Jard, an estate in Lorraine close to Lunéville. The old Einville castle, destroyed by the French during the Thirty Years' War, was rebuilt in 1701 by Leopold, the Duke of Lorraine. During the reign of King Stanisław, the garden with the giant park and its appurtenances was spread over 126 hectares, covering fields and forests. The fields were the place of experiments with new machines and methods of cultivation (Skwarczyńska [Durbas], 2005, pp. 110-113).

The king wished that academicians would take interest also in another devicethe winnowing machine (machine à vanner le bled), a farming machine used for cleaning threshed seeds by separating them from chaffs and other impurities (Nouvelles découvertes..., n.d., p. 23). The advantage of the machine was its incredible efficiency. It was used in the estate named Chantheux (Chanteheux) four kilometres from Lunéville palace, in a straight line from the main garden alley (Skwarczyńska [Durbas], 2005, pp. 104-108).

The device was able to clean as many seeds with one person operating it in one day as four old machines would during one week. Gaining the cleanest and richest seeds was possible because the blow of wind removed not only the chaffs but also dust and other impurities (Nouvelles découvertes ..., n.d., p. 24).

Studies in the field of agriculture at the Stanisław Academy of Sciences (17501766) were connected with new ways of preparing the soil and using improved farming machines in Lorraine. Some of the presented devices could be still found in Poland in the twentieth century. Leszczyński believed that the land was the basic good and agriculture was the driving force in the development of the society, an idea which was similar to those of physiocrats several years later. King Stanisław Leszczyński was the initiator of agricultural innovations, he was inspired by scientific achievements and adapted them in his own scientific experiments. All new solutions were presented during scientific meetings in order to make them widely available. 
Scientific Research in Stanisław Leszczyński Academy in Nancy in the Field of Agriculture and Its Practical Applications (1750-766)

King Stanisław's interest in the development of local agriculture contributed to experimental arable farming, increase in the agricultural production, and mechanisation in agriculture.

\section{References}

Amsterdamski, S. (1983), Między historia a metodą. Spory o racjonalność nauki, Warszawa: Państwowy Instytut Wydawniczy (PWN).

Bonnefont, J. C. (2006), 'Les agronomes de la Société royale des Sciences et BellesLettres de Nancy (1750-1793): Les précurseurs de Mathieu de Dombasle en Lorraine,' Annales de l'Est, no 1.

Credo, A. (1758), Mémoire sur la nouvelle culture, Nancy: Pierre Alliot.

Delarc, O. J. M. (1884-1897), L'église de Paris pendant la Révolution Franc冈aise, 17891801, vol. I, Paris: Desclee, de Brouwer et cie.

Duhamel du Monceau, M. (1750-1757), Traité de la Culture des Terres, vols. 1-5, Paris: H. L. Guerin, L. F. Delatour.

Durbas, M. (2016), 'Ważność drugiej elekcji króla Stanisława Leszczyńskiego w świetle trzeciego traktatu wiedeńskiego,' in M. Markiewicz, D. Rolnik \& F. Wolański (eds.) Wokót wolnych elekcji w państwie polsko-litewskim XVI-XVIII wieku. O znaczeniu idei wyboru - między prawami a obowiazkami, Katowice: Wydawnictwo Uniwersytetu Śląskiego, pp. 449-464.

- (2013), Akademia Stanistawa w Nancy (1750-1766), Krakow: Libron.

Héré, E. (1750), Recueil des plans, élévations et coupes tant géométrales qu'en perspective, des châteaux, jardins et dépendances, que le Roi de Pologne occupe en Lorraine, y compris les batiments qu'il a fait élever ainsi que les changements considérables, les décorations et autres enrichissements qu'il a fait faire à ceux qui étaient dêjà construits. Le tout dédie à Sa Majesté par M. Héré son premier architecte, Ière partie, Paris: François.

Lambel, T. Comte de (2003), Histoire du Château de Fléville, Nancy. Retrieved from https://www.google.ee/search?q=Histoire+du+Ch\%C3\%A2teau+de+Fl\%C3\%A9vi lle\&ie $=\& o e=\#$ [accessed July 2017]

Michaud, L. G., ed. (1821), Biographie universelle, ancienne et moderne: ou Histoire, par ordre alphabétique, de la vie publique et privée de tous les hommes, vol. 29.

Michaux, M. G. (2008), Naissance et développement des académies en France aux XVIIe et XVIIIe siècles, in Mémoires de l'Académie Nationale de Metz, Metz: Académie Nationale de Metz.

Miroudot, J. B. (1760), Mémoire sur le Ray Grass ou Faux Seigle, presenté au Roi de Pologne le 29 juin 1760, Nancy: La Veuve et Claude Leseure. 
M.S.R.N. (1759), Mémoires de la Société Royale des Sciences et Belles-Lettre de Nancy, vol. IV, Nancy: Pierre Antoine.

Nouvelles découvertes... (n.d.), Nouvelles découvertes pour l'avantage et l'utilité du public, [S. Leszczyński], Nancy: Haener.

Pattullo, H. (1759), Essai sur l'amélioration des terres, Paris: Durand.

Précis des fondations... (1758), Précis des fondations et etablissements, fait par sa Majesté le Roi de Pologne, Duc de Lorraine et de Bar, Nancy: Pierre Alliot.

P.V. ms. (1751-1765), Procès-Verbaux-manuscrits de la Société Royale des Lettres, Sciences et Arts de Nancy, vols. I-III.

Rostworowski, E. (1998), Historia powszechna, Warszawa: PWN.

Sauvy, A. \& Hecht, J. (1965), 'La population agricole française au XVIII siécle et expérience du marquis de Turbilly,' Population, vol. 20, no. 2, pp. 269-286. https://doi.org/10.2307/1526327

Skwarczynska [Durbas], M. (2005), Ogrody króla Stanistawa $w$ Lotaryngii $w$ latach 1737-1766, Warszawa: DiG-Warszawa.

Stownik encyklopedyczny francusko-polski (1928), ed. by Z. Matkowski \& S. CiesielskaBorkowska, Lwów \& Warszawa, p. 466.

Statuts de la Societé Royale des Sciences et Belles Lettres de Nancy (1751), Nancy.

Turbilly (1762), Mémoire sur les défrichements par M. Le marquis de Turbilly (L. F. H., de Menon), Amsterdam: M.-M. Rey.

Voisine, J. (1974), "Henry Pattullo's Contribution to the French Enlightenment," Canadian Review of Comparative Literature, vol. 1, no, 2, p. 91-103. Retrieved from https://www.google.ee/search?q=Henry+Pattullo\%E2\%80\%99s.+Contribution+to + the + French + Enlightenment $\&$ ie $=\&$ xoe $=\#[$ accessed July 2017]

Małgorzata Durbas, associate professor at the Institute of History, Academy of Jan Dlugosz in Częstochowa, specialises in the modern history of Poland and the history of relationships between Poland and Lorraine. Her research touches upon the broadly understood cultural and social space of the Duchy of Lorraine and Bar at the time of integration with the House of Bourbon during the reign of King Stanisław Leszczyński. Her academic output includes analyses of many topics concerning the modernisation processes as well as the institutionalisation of academic research, artistic patronage and charity activity. Her current main area of research is the image of the functioning of academic life in the $18^{\text {th }}$ century. 